\title{
Chosen risk factors for osteoporosis and the level of knowledge about the disease in peri- and postmenopausal women
}

\author{
Mariola Janiszewska, Teresa Kulik, Małgorzata A. Dziedzic, Dorota Żołnierczuk-Kieliszek \\ Chair of Public Health, Medical University of Lublin, Lublin, Poland
}

\begin{abstract}
Introduction: Osteoporosis as a chronic disease, affecting especially women in postmenopausal age, is an important, social and economic health problem especially of women of today's world. The aim of the study was to assess the level of knowledge of women in the peri- and postmenopausal period about the prevention of osteoporosis and show the influence of chosen risk factors on the level of this knowledge.

Material and methods: A group of 300 women aged 45-65, being patients of healthcare centres in Chetm, Lublin and Zamość (Lublin voivodeship, south-eastern Poland) were included in the study. The purposive sampling was used. Osteoporosis Knowledge Test (OKT) 2011 was the research tool. Gathered material was subjected to descriptive and statistical analysis. Tukey's test, $t$-student test and variance analysis (ANOVA) were all applied. An accepted $p$ materiality level was $<0.05$ and $p<0.01$.

Results: Respondents presented the average level of knowledge about the role of physical activity in the prevention of osteoporosis $(M=13.93)$ and a low level of knowledge about well-balanced diet rich in calcium $(M=9.77)$. The knowledge about risk factors, screening and treatment remained on the average level $(M=8.00)$. An influence of socio-demographic factors on the level of knowledge was shown. Also some behaviours, associated with the lifestyle indeed influenced the level of this knowledge.

Conclusions: Professional educational programs on osteoporosis should be implemented in the population of Polish peri- and postmenopausal women.
\end{abstract}

Key words: osteoporosis, menopause, level of knowledge, prophylaxis.

\section{Introduction}

Osteoporosis is determined according to the definition of the Foundation and National Institutes of Health - NOF/NIH (2001) as an illness of the skeleton, being characterized by reduced endurance of the bones, which causes an increased risk of fractures. This disease is included among relevant health, social and economic problems of the contemporary world [1-4]. Since the frequency of falling ill is growing with age, therefore in relation to the steady increase of the average life span in the today's society, the number of fractures will be on the increase [1].

Osteoporosis affects the entire population at different life stages; however women in the postmenopausal age and the elderly appear to be most exposed to its development [1]. It is estimated that worldwide osteoporosis affects $200 \mathrm{~m}$ women, from whom about 20-25\% will sustain an injury in the form of a bone fracture [5].

The perimenopausal period, covering a few years preceding the menopause and at least 12 months after the menopause, is unavoidably connected with reduced biosynthesis of oestrogens, being a consequence of reducing and finally stopping the activity of Graafian follicles. The positive effect of oestrogens on the bone tissue, consisting in stimulating osteogenesis and inhibition of the bone resorption process is terminated [ 1 , 6]. Primeval, involutional osteoporosis is characteristic of the postmenopausal period, in which the main loss of the tubercular bone layer over the compact layer, and bone mass loss is caused by exaggerated activity of osteoclasts [1, 2].

In the development of the skeleton one may observe 3 periods, being characterized by a diversified amount of bone mass: growth, maturity, and catagenesis. Bone mass loss during catagenesis can be regarded physiological and then is termed as osteopenia, or wrongly identified with osteoporosis [7].

Most important risk factors for osteoporosis are: age, female sex, ethnic group, genetic factors, inherited factors, early menopause, slim silhouette and low body mass, diseases disturbing the bone metabolism, some medicines taken for a long time, insufficient physical activity, consumption of too small amounts of calcium

\footnotetext{
Corresponding author: Mariola Janiszewska, Chair of Public Health, Medical University of Lublin, 1 Chodźki St., 20-093 Lublin, Poland, e-mail: mariola.janiszewska@gmail.com

To cite this article: Janiszewska M, Kulik T, Dziedzic A, Żołnierczuk-Kieliszek D. Chosen risk factors for osteoporosis and the level of knowledge about the disease in peri- and postmenopausal women. Prz Menopauzalny 2015; 14: 27-34. Submitted: 13.11.2014; Accepted: 4.02.2015.
} 
and vitamin D, overconsumption of alcohol, caffeine and cigarette smoking and protein-rich diet [8].

Recent studies prove that the increased risk of lowenergy bone fracture is the essence of osteoporosis. Discovering the clinical risk factors for osteoporosis fractures and developing the Frax algorithms (WHO Fracture Risk Assessment Tool), by Professor J. A. Kanis in 2008, which enables to calculate the 10 -year probability of major osteoporotic fractures, proves a considerable progress in osteoporosis risk factors research [9].

The Frax algorithms take into account clinical risk factors for osteoporosis fractures, body mass index (BMI) and bone mineral density (BMD) $T$-score of the femoral neck. Clinical risk factors for osteoporosis fractures are as follows: age between 40 and 90 years, female gender, previous osteoporotic fracture, parent fractured hip, active tobacco smoking, excess alcohol consumption over $30 \mathrm{mg}$ of alcohol per day, taking glucocorticoids for 3 months or longer at present or in the past, rheumatoid arthritis, and secondary osteoporosis [4].

The foundation of preventive actions in the aspect of osteoporosis is relevant diet throughout the entire life [10]. The appropriate amount of calcium in the diet constitutes the factor assisting in getting top bone mass in the period of growing as well as in keeping the state of the bone tissue at the appropriate level in the postmenopausal period [11]. Vitamin D is essential for supporting the normal process of absorbing calcium from intestines. It was proved that vitamin $D$ and its active metabolites have a positive effect on the quality and density of bone mass $[12,13]$.

In prevention of osteoporosis, a well-comprehended physical activity, being an essential factor of the normal development of the bone tissue and keeping the bone metabolism on the desirable level plays a crucial role [14].

Both in Poland and all over the world, many patients suffering from osteoporosis fractures do not undergo further diagnostic procedures and do not receive pharmacologic treatment for osteoporosis. This is why the International Osteoporosis Foundation (IOF) launched an international campaign 'Capture the fracture'. The main aim of the campaign is to 'detect osteoporotic fractures and referring patients to out-patient clinics specializing in the diagnosis and treatment of osteoporosis. The campaign should reduce the number of osteoporotic fractures in the future $[15,16]$. The aim of the present study was to determine the state of knowledge of peri- and postmenopausal women about the prevention of osteoporosis and showing predictor models affecting the level of this knowledge which can turn out to be helpful in formulating relevant preventive programs.

\section{Material and methods}

The study was conducted in the period from 2 January to 30 March 2012 on a group of 300 women at the age range of 45 to 65 , being patients of healthcare centres in Chełm, Lublin and of surroundings of Zamość (Lublin voivodeship, south-eastern Poland). The purposive sampling was used.

The Osteoporosis Knowledge Test (OKT) (2011) was used to perform own examinations. The OKT is a tool consisting of 32 elements evaluating the knowledge in applying a well-balanced diet with a lot of products rich in calcium, essential for construction and keeping mass of the bone; the physical activity and risk factors, screening and treatment of osteoporosis. In order to set the operands, and hence to present characteristics of the research group, the questionnaire prepared by the author was used, containing 13 questions.

The empirical material was subjected to descriptive and statistical analysis. Tukey's test, $t$-Student test and variance analysis (ANOVA) were all applied. An accepted $p$ materiality level was $<0.05$ and $p<0.01$. Computer software IBM SPSS Statistics 19 was applied.

The examined group comprised women at the age from 45 to 65 . Seventy-seven percent of respondents were aged $45-55$ years $(n=321)$. The remaining women were from 56 up to 65 years of age $(n=69 ; 53 \%)$. Considering the level of education it turned out that almost $40 \%$ of the examined women had secondary education $(n=119), 43(14.3 \%)$ vocational education and $14 \%$ $(n=42)$ higher education.

As regards socio-economic conditions, 51.3\% ( $n=154)$ of the examined women described them as good, however $30.3 \%(n=91)$ as average. The scanty percentage complained about bad conditions ( $n=6$, $2.0 \%$ ). For a fuller picture of the examined group, respondents were asked about reporting for densitometry. As it turned out a significant number of examined women had never had bone density examined $(n=208$; $69.3 \%$ ), and 3 individuals out of examined were not sure what such an examination consists in.

\section{Results}

As regards the acquaintance of risk factors for osteoporosis amongst women in the perimenopausal period, it was shown that the majority of respondents (77.6\%) agreed with the fact that a low calcium diet constitutes an essential risk factor for osteoporosis. Older age was indicated by $89.4 \%$ of the examined women, and the menopausal period in women by $85.4 \%$. Unfortunately, only $34 \%$ and $41.7 \%$ of respondents connected dipsomania and cigarette smoking, respectively, with the possibility of falling ill with osteoporosis. Actually the comprehended physical activity and applying the diet rich in calcium constitute fundamental links with reference to the prevention of osteoporosis.

Most respondents thought that cycling was the best way of preventing osteoporosis (61.3\%), swimming (43\%), running (48.3\%) and aerobics (65\%) being next in 
turn, whereas with the best source of calcium - cheese (98\%), sardine (44.7\%), meat of the chicken (61\%), yogurt (95\%) and ice-cream (48\%). Majority of respondents declared that for correct absorbing of calcium, vita- min D was essential (70\%), which is provided by sunlight (67\%). Unfortunately, only $13 \%$ of women indicated growing up as the optimum period in life for building strong bones. The above data are presented in Table I.

Tab. I. Knowledge of respondents on osteoporosis

\begin{tabular}{|c|c|c|c|c|}
\hline & Very probable & Little probable & No impact & I don't know \\
\hline Eating a diet low in dairy products & $77.6 \%$ & $14.7 \%$ & $6.7 \%$ & $1 \%$ \\
\hline Being menopausal; "change of life" & $85.4 \%$ & $5 \%$ & $4.3 \%$ & $5.3 \%$ \\
\hline $\begin{array}{l}\text { Having a parent or grandparent who has/had } \\
\text { osteoporosis }\end{array}$ & $53.3 \%$ & $20 \%$ & $15 \%$ & $11.7 \%$ \\
\hline Being a white and Asian woman & $31.3 \%$ & $14.3 \%$ & $18.7 \%$ & $35.7 \%$ \\
\hline Being an elderly man & $89.4 \%$ & $5 \%$ & $3.3 \%$ & $2.3 \%$ \\
\hline Having ovaries surgically removed & $32.3 \%$ & $15.7 \%$ & $20.7 \%$ & $31.3 \%$ \\
\hline $\begin{array}{l}\text { Taking cortisone (steroids e.g. prednisone) } \\
\text { for a long time }\end{array}$ & $29.7 \%$ & $12.7 \%$ & $7.3 \%$ & $50.3 \%$ \\
\hline Being overweight & $48.7 \%$ & $22.7 \%$ & $19 \%$ & $9.6 \%$ \\
\hline Having an eating disorder & $94 \%$ & $1.7 \%$ & $1.3 \%$ & $3 \%$ \\
\hline Consuming more than 2 alcoholic drinks per day & $34 \%$ & $24.7 \%$ & $24 \%$ & $17.3 \%$ \\
\hline Smoking on a daily basis & $41.7 \%$ & $25 \%$ & $17.3 \%$ & $16 \%$ \\
\hline $\begin{array}{l}\text { To strengthen bones, it is recommended that } \\
\text { a person exercise at a moderately intense level } \\
\text { for } 30 \text { minutes a day at least }\end{array}$ & $\begin{array}{c}51 \% \\
3 \text { days a week }\end{array}$ & $\begin{array}{c}10.3 \% \\
4 \text { days a week }\end{array}$ & $\begin{array}{c}14.7 \% \\
5 \text { days a week }\end{array}$ & $\begin{array}{l}24 \% \\
\text { I don't know }\end{array}$ \\
\hline $\begin{array}{l}\text { Exercise makes bones strong, but it must be } \\
\text { hard enough to make breathing }\end{array}$ & $\begin{array}{l}41 \% \\
\text { Just a little faster }\end{array}$ & $\begin{array}{l}2.7 \% \\
\text { Much faster, but } \\
\text { talking is possible }\end{array}$ & $\begin{array}{l}2.3 \% \\
\text { So fast that talk- } \\
\text { ing is not possible }\end{array}$ & $\begin{array}{l}36 \% \\
\text { I don't know }\end{array}$ \\
\hline $\begin{array}{l}\text { Which of the following activities is the best } \\
\text { way to reduce a person's chance of getting } \\
\text { osteoporosis? }\end{array}$ & $\begin{array}{l}43 \% \\
\text { Swimming }\end{array}$ & $\begin{array}{l}29 \% \\
\text { Brisk walking }\end{array}$ & $\begin{array}{l}9 \% \\
\text { Stretching }\end{array}$ & $\begin{array}{l}19 \% \\
\text { I don't know }\end{array}$ \\
\hline $\begin{array}{l}\text { Which of the following activities is the best } \\
\text { way to reduce a person's chance of getting } \\
\text { osteoporosis? }\end{array}$ & $\begin{array}{l}61.3 \% \\
\text { Cycling }\end{array}$ & $\begin{array}{l}20 \% \\
\text { Yoga }\end{array}$ & $\begin{array}{l}0.7 \% \\
\text { Lifting weights }\end{array}$ & $\begin{array}{l}18 \% \\
\text { I don't know }\end{array}$ \\
\hline $\begin{array}{l}\text { Which of the following activities is the best } \\
\text { way to reduce a person's chance of getting } \\
\text { osteoporosis? }\end{array}$ & $\begin{array}{l}48.3 \% \\
\text { Jogging and run- } \\
\text { ning }\end{array}$ & $\begin{array}{l}\quad 7.7 \% \\
\text { Golfing using } \\
\text { a golf cart }\end{array}$ & $\begin{array}{c}22.7 \% \\
\text { Gardening }\end{array}$ & $\begin{array}{l}21.3 \% \\
\text { I don't know }\end{array}$ \\
\hline $\begin{array}{l}\text { Which of the following activities is the best } \\
\text { way to reduce a person's chance of getting } \\
\text { osteoporosis? }\end{array}$ & $\begin{array}{l}5 \% \\
\text { Bowling }\end{array}$ & $\begin{array}{c}4.3 \% \\
\text { Doing laundry }\end{array}$ & $\begin{array}{l}65 \% \\
\text { Aerobic dancing }\end{array}$ & $\begin{array}{c}25.7 \% \\
\text { I don't know }\end{array}$ \\
\hline Which of these is the best source of calcium? & $\begin{array}{c}1 \% \\
\text { Apples }\end{array}$ & $\begin{array}{c}98 \% \\
\text { Cheeses }\end{array}$ & $\begin{array}{c}0 \% \\
\text { Cucumbers }\end{array}$ & $\begin{array}{c}1 \% \\
\text { I don't know }\end{array}$ \\
\hline Which of these is the best source of calcium? & $\begin{array}{c}26 \% \\
\text { Peanut butter }\end{array}$ & $\begin{array}{c}26 \% \\
\text { Turkey meat }\end{array}$ & $\begin{array}{c}44.7 \% \\
\text { Canned sardines }\end{array}$ & $\begin{array}{c}3.3 \% \\
\text { I don't know }\end{array}$ \\
\hline Which of these is the best source of calcium? & $\begin{array}{c}61 \% \\
\text { Chicken }\end{array}$ & $\begin{array}{l}26.3 \% \\
\text { Broccoli }\end{array}$ & $\begin{array}{l}2.4 \% \\
\text { Grapes }\end{array}$ & $\begin{array}{c}10.3 \% \\
\text { I don't know }\end{array}$ \\
\hline Which of these is the best source of calcium? & $\begin{array}{c}95 \% \\
\text { Yoghurt }\end{array}$ & $\begin{array}{c}1 \% \\
\text { Strawberries }\end{array}$ & $\begin{array}{c}3 \% \\
\text { Cabbage }\end{array}$ & $\begin{array}{c}1 \% \\
\text { I don't know }\end{array}$ \\
\hline Which of these is the best source of calcium? & $\begin{array}{c}48 \% \\
\text { Ice-cream }\end{array}$ & $\begin{array}{c}15 \% \\
\text { Grape fruit }\end{array}$ & $\begin{array}{c}8 \% \\
\text { Radishes }\end{array}$ & $\begin{array}{c}29 \% \\
\text { I don't know }\end{array}$ \\
\hline $\begin{array}{l}\text { Which of the following is the recommended } \\
\text { amount of calcium intake for an adult? }\end{array}$ & $\begin{array}{c}16 \% \\
600-800 \text { mg daily }\end{array}$ & $\begin{array}{l}39 \% \\
1000-1200 \mathrm{mg} \\
\text { daily }\end{array}$ & $\begin{array}{l}3 \% \\
1400-1600 \mathrm{mg} \\
\text { daily }\end{array}$ & $\begin{array}{l}42 \% \\
\text { I don't know }\end{array}$ \\
\hline $\begin{array}{l}\text { How much milk must an adult drink to meet } \\
\text { the recommended amount of calcium? }\end{array}$ & $\begin{array}{l}53 \% \\
1 \text { glass }\end{array}$ & $\begin{array}{c}26 \% \\
2 \text { glasses }\end{array}$ & $\begin{array}{l}15 \% \\
3 \text { or more glasses }\end{array}$ & $\begin{array}{l}6 \% \\
\text { I don't know }\end{array}$ \\
\hline $\begin{array}{l}\text { Which of following is the best reason for taking } \\
\text { a calcium supplement? }\end{array}$ & $\begin{array}{l}3.3 \% \\
\text { If a person skips } \\
\text { breakfast }\end{array}$ & $\begin{array}{l}58 \% \\
\text { If a person does } \\
\text { not get enough } \\
\text { calcium from diet }\end{array}$ & $\begin{array}{l}34.7 \% \\
\text { If a person is over } \\
45 \text { years old }\end{array}$ & $\begin{array}{l}4 \% \\
\text { I don't know }\end{array}$ \\
\hline
\end{tabular}


Tab. I. Cont.

\begin{tabular}{|c|c|c|c|c|}
\hline & Very probable & Little probable & No impact & I don't know \\
\hline $\begin{array}{l}\text { Which vitamin is required for the absorption } \\
\text { of calcium? }\end{array}$ & $\begin{array}{c}6 \% \\
\text { Vitamin A }\end{array}$ & $\begin{array}{l}8 \% \\
\text { Vitamin C }\end{array}$ & $\begin{array}{l}70 \% \\
\text { Vitamin D }\end{array}$ & $\begin{array}{c}16 \% \\
\text { I don't know }\end{array}$ \\
\hline $\begin{array}{l}\text { What is the best source of vitamin required for } \\
\text { the absorption of calcium? }\end{array}$ & $\begin{array}{l}12 \% \\
\text { Carrot }\end{array}$ & $\begin{array}{c}3 \% \\
\text { Orange }\end{array}$ & $\begin{array}{c}67 \% \\
\text { Sunlight }\end{array}$ & $\begin{array}{l}18 \% \\
\text { I don't know }\end{array}$ \\
\hline $\begin{array}{l}\text { What is the best food source of the vitamin } \\
\text { required for the absorption of calcium? }\end{array}$ & $\begin{array}{c}20 \% \\
\text { Spinach }\end{array}$ & $\begin{array}{c}46 \% \\
\text { Cheeses }\end{array}$ & $\begin{array}{l}21 \% \\
\text { Salmon }\end{array}$ & $\begin{array}{c}13 \% \\
\text { I don't know }\end{array}$ \\
\hline $\begin{array}{l}\text { Which of the following is the recommended } \\
\text { amount of vitamin required for the absorption } \\
\text { of calcium for an adult, } 50 \text { years old and older? }\end{array}$ & $\begin{array}{c}13 \% \\
800-1000 \text { IU daily }\end{array}$ & $\begin{array}{l}32 \% \\
1200-1400 \text { IU } \\
\text { daily }\end{array}$ & $\begin{array}{l}7 \% \\
1600-1800 \text { IU } \\
\text { daily }\end{array}$ & $\begin{array}{c}48 \% \\
\text { I don't know }\end{array}$ \\
\hline When is the best time to build strong bones? & $\begin{array}{l}63 \% \\
\text { Childhood }\end{array}$ & $\begin{array}{c}29 \% \\
\text { Adolescence }\end{array}$ & $\begin{array}{c}5 \% \\
\text { Young adulthood }\end{array}$ & $\begin{array}{c}3 \% \\
\text { I don't know }\end{array}$ \\
\hline Osteoporosis can be diagnosed by & $\begin{array}{c}4 \% \\
\text { Blood test }\end{array}$ & $\begin{array}{c}88.3 \% \\
\text { DXA scan }\end{array}$ & $\begin{array}{c}4 \% \\
\text { Symptoms }\end{array}$ & $\begin{array}{c}3.7 \% \\
\text { I don't know }\end{array}$ \\
\hline Once you have osteoporosis & $\begin{array}{l}2 \% \\
\text { There is noth- } \\
\text { ing you can do } \\
\text { about it }\end{array}$ & $\begin{array}{l}90 \% \\
\text { You can take } \\
\text { medication to } \\
\text { treat it }\end{array}$ & $\begin{array}{l}5.7 \% \\
\text { You must be care- } \\
\text { ful when lifting } \\
\text { objects }\end{array}$ & $\begin{array}{c}2.3 \% \\
\text { I don't know }\end{array}$ \\
\hline
\end{tabular}

Summing up, women in the peri- and postmenopausal age presented a medium level of knowledge on the role of physical activity in osteoporosis prophylaxis $(M=13.93)$ and a low level of knowledge related to problems connected with proper diet rich in calcium $(M=9.77)$. Knowledge about risk factors, screen tests and the treatment remained on a medium level $(M=8.00)$. The questioned women presented insufficient general knowledge on osteoporosis $(M=15.71)$. The data are presented in Table II.

Analysing the influence of education on the level of women's knowledge about osteoporosis it can be stated that the level of education was diversifying respondents in terms of the presented knowledge about the role of a diet rich in calcium in the aspect of preventing osteoporosis. Women with primary and vocational education had significantly smaller knowledge on this subject than women with secondary and higher education. However, important differences were not observed between women with secondary and higher education. The same applied to the influence of education as the level of knowledge about the role of physical activity, risk factors, screening and treatment and of general knowledge about osteoporosis (Fig. 1).

Examining the influence of socio-economic conditions on the level of knowledge of respondents, it was stated that individuals declaring very good socio-eco- nomic conditions had indeed presented the highest level of knowledge $(M=8.61)$ about risk factors, screening and treatment of osteoporosis as compared to individuals having average or bad socio-economic conditions. However, differences close to the statistical significance occurred for knowledge about nutrition (biggest in individuals with good socio-economic conditions $[M=$ 14.31], and smallest in individuals with average or bad socio-economic conditions [ $M=13.34]$ ) and knowledge about the role of physical activity (biggest amongst individuals with very good socio-economic conditions $[M=10.49]$, and smallest in individuals with average or bad socio-economic conditions [ $M=9.37]$ ). The above relations are described in Table III.

Analysing the influence of age on the level of knowledge about osteoporosis, one should notice that younger women aged 45 to 55 years old had a significantly higher level of knowledge about the role of physical activity $(M=10.03)$ than older women (56-65 years old) $(M=8.91)$. Younger women also had the highest level of knowledge indeed about risk factors, screening and treatment $(M=8.26)$ than older women $(M=7.12)$. The above relations are described in Table IV.

Physical activity is a boost of bone tissue to develop top bone mass in the young age whereas in the elderly it hinders the disintegration of this bone tissue. It is also proved that long-term immobilizing, or neglecting

Tab. II. Knowledge on osteoporosis: summing up

\begin{tabular}{lccccc}
\hline Test of knowledge on osteoporosis & $\boldsymbol{N}$ & Min & Max & M & SD \\
\hline Knowledge about the role of physical activity & 300 & 4 & 23 & 13.93 & 3.36 \\
\hline Knowledge about nutrition - calcium consumption & 300 & 0 & 17 & 9.77 & 2.90 \\
\hline Knowledge about risk factors, screen tests and treatment & 300 & 0 & 14 & 8.00 & 2.45 \\
\hline General knowledge about osteoporosis & 300 & 4 & 25 & 15.71 & 3.83 \\
\hline
\end{tabular}


the role of everyday physical exercises (walking, gymnastics, running or walking up the stairs) for the structure and development of the skeleton, causes a fall in bone mass [14]. Examining the influence of physical activity on the level of knowledge about osteoporosis it was pointed out that women who are active in terms of physicality were characterized indeed by a high level of knowledge about the role of feeding, physical activity, risk factors and generally osteoporosis than women not practising sport (Fig. 2).

Diagnosing the osteoporosis is based, among others, on the lower bone mineral density (BMD) (in $\mathrm{g} / \mathrm{cm}^{2}$ ). Bone mineral density is an indicator of resistance of the bone structure, that is, it is responsible for $70 \%$ of its endurance [17]. Our own studies show that the above examination had no impact on the level of knowledge on the prevention of osteoporosis. Women examined were characterized by the highest level of knowledge about correct nutrition and with the highest level of general knowledge about osteoporosis than women who they did not have their bone mineral density determined. Additionally respondents, at whom such an

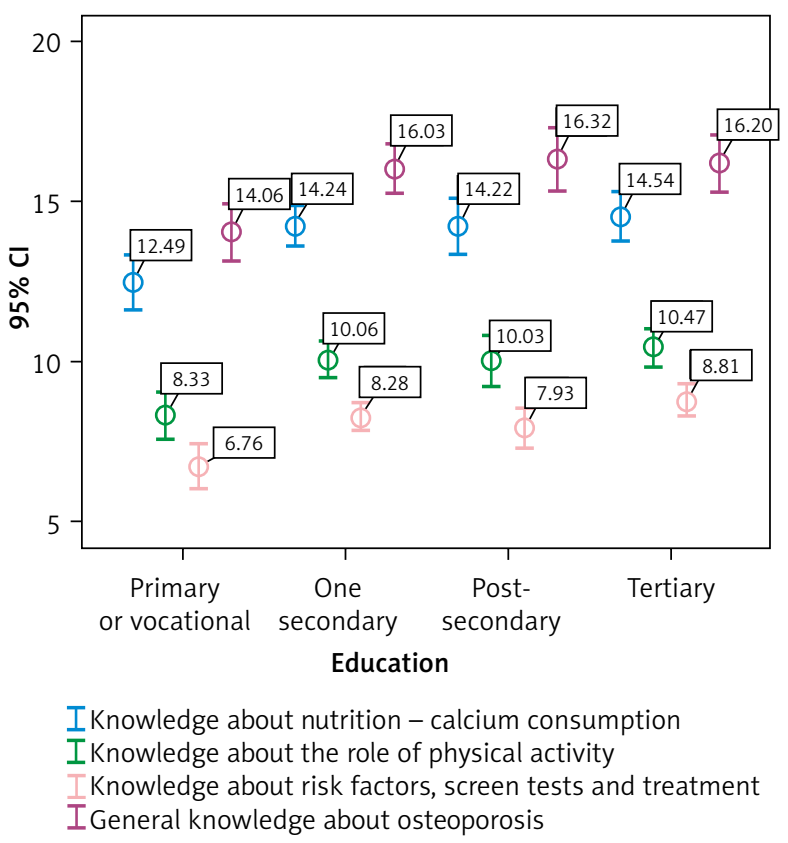

Fig. 1. The influence of education on the level of knowledge about osteoporosis

Tab. III. Impact of socio-economic conditions on the level of knowledge about osteoporosis

\begin{tabular}{|c|c|c|c|c|c|c|c|}
\hline \multirow[t]{2}{*}{ Level of knowledge } & \multirow{2}{*}{$\begin{array}{l}\text { Socio-economic } \\
\text { conditions }\end{array}$} & \multicolumn{5}{|c|}{ Anova } & \multirow[t]{2}{*}{ Tukey's test } \\
\hline & & $N$ & $M$ & $S D$ & $F$ & $p$ & \\
\hline \multirow{3}{*}{$\begin{array}{l}\text { On nutrition } \\
\text { (calcium } \\
\text { consumption) }\end{array}$} & Very good (1) & 49 & 13.90 & 3.42 & 2.51 & 0.083 & \\
\hline & Good (2) & 154 & 14.31 & 3.37 & & & \\
\hline & Average or bad (3) & 97 & 13.34 & 3.27 & & & \\
\hline \multirow{3}{*}{$\begin{array}{l}\text { On the role } \\
\text { of physical activity }\end{array}$} & Very good (1) & 49 & 10.49 & 2.57 & 2.45 & 0.083 & \\
\hline & Good (2) & 154 & 9.80 & 2.95 & & & \\
\hline & Average or bad (3) & 97 & 9.37 & 2.93 & & & \\
\hline \multirow{3}{*}{$\begin{array}{l}\text { On risk factors, } \\
\text { screen tests } \\
\text { and treatment }\end{array}$} & Very good (1) & 49 & 8.61 & 2.29 & 3.42 & $0.034^{*}$ & \multirow{3}{*}{$p=0.033^{*}$} \\
\hline & Good (2) & 154 & 8.09 & 2.42 & & & \\
\hline & Average or bad (3) & 97 & 7.54 & 2.53 & & & \\
\hline \multirow{3}{*}{$\begin{array}{l}\text { General knowledge } \\
\text { about osteoporosis }\end{array}$} & Very good (1) & 49 & 15.78 & 3.73 & 1.46 & 0.235 & \\
\hline & Good (2) & 154 & 16.02 & 3.92 & & & \\
\hline & Average or bad (3) & 97 & 15.18 & 3.73 & & & \\
\hline
\end{tabular}

Tab. IV. Influence of the age on the level of knowledge about osteoporosis

\begin{tabular}{|c|c|c|c|c|c|c|}
\hline \multirow[t]{3}{*}{ Level of knowledge } & \multicolumn{4}{|c|}{ Age } & \multicolumn{2}{|c|}{$t$-Student test } \\
\hline & \multicolumn{2}{|c|}{$45-55$} & \multicolumn{2}{|c|}{$56-65$} & \multirow[b]{2}{*}{$t$} & \multirow[b]{2}{*}{$p$} \\
\hline & $M$ & $S D$ & $M$ & $S D$ & & \\
\hline On nutrition (calcium consumption) & 14.08 & 3.43 & 13.43 & 3.10 & 1.40 & 0.164 \\
\hline On the role of physical activity & 10.03 & 2.83 & 8.91 & 2.99 & 2.84 & $0.005^{\star *}$ \\
\hline On risk factors, screen tests and treatment & 8.26 & 2.42 & 7.12 & 2.39 & 3.46 & $0.001^{* *}$ \\
\hline General knowledge about osteoporosis & 15.85 & 3.89 & 15.23 & 3.63 & 1.17 & 0.242 \\
\hline
\end{tabular}




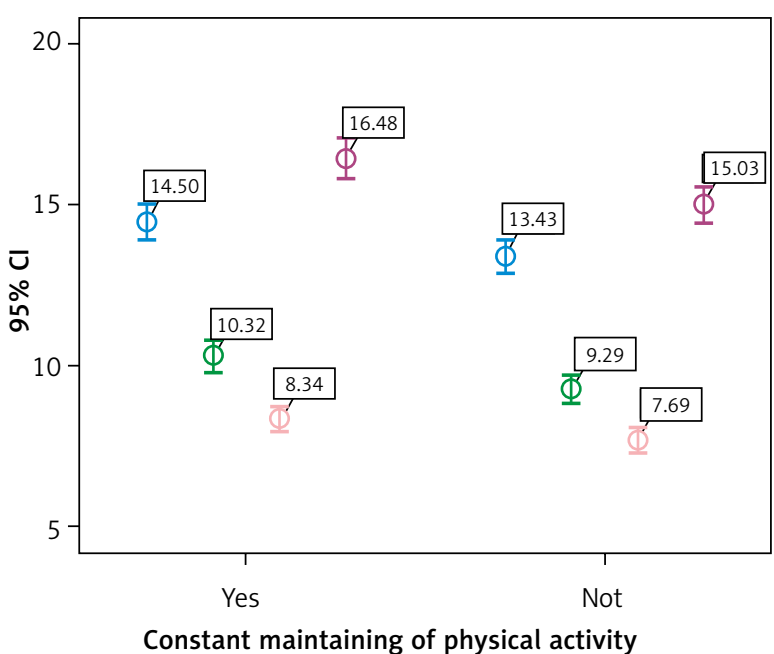

IKnowledge about nutrition - calcium consumption IKnowledge about the role of physical activity

T Knowledge about risk factors, screen tests and treatment IGeneral knowledge about osteoporosis

Fig. 2. The impact of good physical condition on the level of knowledge about osteoporosis

examination was performed had a significantly bigger knowledge about the role of physical activity and about risk factors for screening and treatment (Table V).

Cigarette smoking hinders action of osteoblasts and disturbs processes of absorbing calcium. A connection exists between cigarette smoking and the increase in frequency of osteoporotic fractures [12]. Based on our own examinations, it may be stated that the fact of cigarette smoking was diversifying examined women in terms of the level of knowledge about osteoporosis. As it turned out higher knowledge about risk factors, screening and treatment was presented by smoking individuals $(M=8.49)$ than non-smoking individuals $(M=7.81)$. Results are presented in Table VI.

\section{Discussion}

Osteoporosis is one of main medical and social problems and along with a longer average life span in the developed countries, more cases of osteoporosis can be expected in the near future and in consequence more osteoporotic fractures [18]. Especially women in the postmenopausal age are predisposed to lowenergy fractures, therefore it is predicted that almost half of women, aged over 50 , will be affected by the fracture [19].

Our own examinations showed that the level of knowledge of the majority of women about principles of correct nutrition was insufficient and such knowledge remained in the close relationship with the education and socio-economic status. Straight majority of women having secondary and higher education and enjoying better socio-economic conditions had the highest level of knowledge about a calcium-rich diet. Results of the majority of research confirm these correlations with osteoporosis. Turkish studies by Gemalaza et al. are an example [20] of noticing a relation of the knowledge in this respect.

Also studies conducted in Vietnam by Nguyen et al. [21] and by Costa-Paiva et al. [22] in Sao Paulo in Brazil

Tab. V. Densitometry and knowledge of osteoporosis

\begin{tabular}{|c|c|c|c|c|c|c|}
\hline \multirow[t]{3}{*}{ Level of knowledge } & \multicolumn{4}{|c|}{ Densitometry done to exclude the risk of osteoporosis } & \multicolumn{2}{|c|}{$t$-Student test } \\
\hline & \multicolumn{2}{|c|}{ Yes } & \multicolumn{2}{|c|}{ No } & \multirow[b]{2}{*}{$t$} & \multirow[b]{2}{*}{$p$} \\
\hline & $M$ & $S D$ & $M$ & $S D$ & & \\
\hline On nutrition (calcium consumption) & 15.05 & 2.87 & 13.46 & 3.42 & 3.80 & $0.000^{* *}$ \\
\hline On the role of physical activity & 10.29 & 2.58 & 9.54 & 3.00 & 2.03 & $0.043^{*}$ \\
\hline On risk factors, screen tests and treatment & 8.49 & 2.10 & 7.77 & 2.54 & 2.31 & $0.022^{*}$ \\
\hline General knowledge about osteoporosis & 16.85 & 3.36 & 15.23 & 3.91 & 3.37 & $0.001^{* *}$ \\
\hline
\end{tabular}

Tab. VI. Cigarette smoking and the level of knowledge on osteoporosis

\begin{tabular}{|c|c|c|c|c|c|c|}
\hline \multirow[t]{3}{*}{ Level of knowledge } & \multicolumn{4}{|c|}{ Cigarette smoking } & \multicolumn{2}{|c|}{$t$-Student test } \\
\hline & \multicolumn{2}{|c|}{ Yes } & \multicolumn{2}{|c|}{ No } & \multirow[b]{2}{*}{$t$} & \multirow[b]{2}{*}{$p$} \\
\hline & $M$ & $S D$ & $M$ & $S D$ & & \\
\hline On nutrition (calcium consumption) & 14.40 & 3.45 & 13.75 & 3.32 & 1.49 & 0.137 \\
\hline On the role of physical activity & 10.30 & 3.06 & 9.57 & 2.82 & 1.96 & 0.051 \\
\hline On risk factors, screen tests and treatment & 8.49 & 2.38 & 7.81 & 2.46 & 2.18 & $0.030^{*}$ \\
\hline General knowledge about osteoporosis & 16.20 & 4.00 & 15.52 & 3.76 & 1.39 & 0.164 \\
\hline
\end{tabular}


demonstrated an identical relation. In both cases the level of knowledge was determined as low. Women in the perimenopausal age should care for the appropriate supply of calcium of even up to 1500 mg a day. However, scarcely $13 \%$ of respondents pointed correctly at this dose for the adult man, $48 \%$ of women concluded about the recommended dose of calcium with a reply "I don't know". Filip [23] pays attention to insufficient supplementing of calcium amongst women in the postmenopausal age, applied mainly by order of the doctor. Also Kasper et al. [24] prove a little interest of women in supplementing calcium ( $6.7 \%$ of respondents).

Properly comprehended, everyday physical activity has a beneficial effect on the structure and keeping bone mass in every age. Our own examinations showed that women had an average but insufficient level of knowledge about the role of regular physical exercise, which largely depended on the level of education and socio-economic conditions. Pilewska et al. [25], examining the influence of the physical activity on osteoporosis, presented data saying that only $17.3 \%$ of women aged 45-60 confirmed performing regular physical exercises for 1-2 hours every week.

Also Szczygielska-Majewska et al. [26], after conducting their examinations concerning a lifestyle in the aspect of the prevention of osteoporosis, demonstrated that as many as $65.8 \%$ of individuals examined by them did not carry out any form of physical exercise. Hernandez-Rauda et al. [27] confirmed this fact by carrying out research in San Salvador, on the basis of which it was stated that a little percentage of women of different ages only practised any form of physical exercise.

In our own examinations, a level of knowledge of perimenopausal women about risk factors, screening and treatment of osteoporosis was determined as average but insufficient and to a considerable degree depending on the education and socio-economic status. In spite of the fact that majority of respondents (77.6\%) agreed with the fact that the diet of low calcium content constitutes an essential risk factor for osteoporosis, only $34 \%$ and $41.7 \%$ of respondents connected alcohol abuse and cigarette smoking, respectively, with the possibility of falling ill with osteoporosis. Indian examinations (Sapna et al. [28]) confirm that only less than a half of the examined women regarded early menopause, alcohol abuse and wrong diet as risk factors for osteoporosis.

Also Spencer [29] examining the Scottish population demonstrated a considerable deficiency of the knowledge on risk factors. The largest group of the examined people (31.8\%) had no knowledge on the above subject, whereas $19.3 \%$ of respondents did not know how to prevent osteoporosis. Examinations conducted in the George University Freemason (Washington, D.C.), including a group of women aged 22-84, demonstrated an insufficient level of knowledge on risk factors and prevention of osteoporosis [30].

\section{Conclusions}

1. Peri- and postmenopausal women presented an average level of knowledge about the role of physical activity in osteoporosis prevention and a low level of knowledge with reference to issues associated with a well-balanced diet rich in calcium.

2. The respondents had an average, but insufficient, knowledge on risk factors, screening and treatment and general knowledge of osteoporosis.

3. Socio-demographic factors as well as some forms of behaviour, associated with a lifestyle, such as regular physical activity, prophylactic examinations and cigarette smoking indeed influenced the level of knowledge possessed.

\section{Disclosure}

Authors report no conflict of interest.

\section{References}

1. Grywalska E, Grafka A, Putowski L, et al. Komórki macierzyste w leczeniu złamań towarzyszących osteoporozie - medyczne science fiction czy metoda terapii w przyszłości? Prz Menopauzalny 2010; 9: 378-382.

2. Lorenc R, Głuszko P, Karczmarewicz E. Zalecenia postępowania diagnostycznego i leczniczego w osteoporozie. Aktualizacja 2013. Med Prakt 2013; Wyd. Spec. 1: 1-44.

3. Sewerynek E, Horst-Sikorska W, Stępień-Kłos, et al. The role of counselling and other factors in compliance of postmenopausal osteoporotic patients to alendronate 70 therapy. Arch Med Sci 2013; 9: 288-296.

4. Kanis J, McCloskey EV, Johansson $\mathrm{H}$, et al. European guidance for the diagnosis and management of osteoporosis in postmenopausal women. Osteoporosis Int 2012; 24: 23-57.

5. Gmiński J. Znaczenie postępowania leczniczego w leczeniu osteoporozy dla jakości życia kobiet w wieku menopauzalnym. Prz Menopauzalny 2002; 1: 53-59.

6. Bączyk G, Opala T, Kleka P, et al. Multifactorial analysis of risk factors for reduced bone mineral density among postmenopausal women. Arch Med Sci 2012; 8: 332-341.

7. Laskowska A. Rola pielęgniarki i położnej w profilaktyce osteoporozy wśród dorosłych. Pielęg Położna 2005; 6: 19-22.

8. Hogson S. Co radzi lekarz. Osteoporoza. Świat Książki, Warszawa 2007.

9. Marcinowska-Suchowierska E, Czerwiński E, Badurski J, et al. Osteoporoza - diagnostyka i terapia u osób starszych. Post Nauk Med 2011; 5: 410-423.

10. Dżygadło B, Łepecka-Klusek C. Zastosowanie niektórych substancji mających wpływ na obrót kostny. Med Ogólna 2012; 18: 125-130.

11. Knypl K. Osteoporozy - wybrane zagadnienia. Geriat Pol 2005; 1: 43-46.

12. Chwojnowska Z, Charzewska J. Osteoporoza - aktualne wyzwanie. Żyw Człow 2008; 35: 151-184.

13. Halaba Z. Profilaktyka osteoporozy. In: Osteoporoza. Praktyczne zasady opieki lekarskiej nad chorym z osteoporozą. Pluskiewicz G (ed.). Med Trib Pol, Warszawa 2010; 67-70.

14. Nawrot-Szołtysik A, Żmudzka-Wilczek E, Doroniewicz I. Profilaktyka i usprawnianie ruchowe $u$ chorych $z$ osteoporozą. Rehabil Prakt 2010; 1: 21-24.

15. Akesson K, Marsh D, Mitchell PJ, et al. Capture the fracture: a best practice framework and global campaign to break the fragility fracture cycle. Osteoporosis Int 2013; 24: 2135-2152.

16. Głuszko P. Osteoporoza - postępy 2013. Med Prakt 2014; 3: 37-43.

17. Osieleniec J. Diagnoza: osteoporoza. Mag Pielęg Położ 2011; 6: 22-23.

18. Miazgowski T. Prospektywna ocena częstości występowania osteoporotycznych złamań kręgów w losowo wybranej próbce populacyjnej. Endokrynol Pol 2005; 2: 154-159. 
19. Męczkalski B, Czyżyk A. Konwencjonalna hormonalna terapia zastępcza w leczeniu osteoporozy. Pol Merkuriusz Lek 2009; 27: 72-76.

20. Gemalmaz A, Oge A. Knowledge and awareness about osteoporosis and its related factors among rural Turkish women. Clin Rheumatol 2008; 27: 723-728.

21. Nguyen N, Dinh T, Ngo Q, et al. Awareness and knowledge of osteoporosis in Vietnamese women. Asia Pac J Public Health 2011; 14 [Epub ahead of print].

22. Costa-Paiva L, Gomes D, Morais S, et al. Knowledge about osteoporosis in postmenopausal women undergoing antiresorptive treatment. Maturitas 2011; 69: 81-85.

23. Filip R. Opinie i postawy kobiet wobec leczenia suplementacyjnego preparatami wapnia i witaminy D3. Zdr Publ 2006; 116: 241-245.

24. Kasper M, Peterson M, Allegrante J, et al. Knowledge, beliefs and behaviors among college women concerning the prevention of osteoporis. Arch Fam Med 1994; 3: 696-702.
25. Pilewska A, Kanadys K, tepecka-Klusek C, et al. Aktywność fizyczna kobiet jako profilaktyka osteoporozy. Ann UMCS Sect D 2003; 58: 231235.

26. Szczygielska-Majewska M, Papis E. Styl życia a osteoporoza. Ann UMCS Sect D 2003; 58: 243-246.

27. Hernandez-Rauda R, Martinez-Garcia S. Osteoporosis-related life habits and knowledge about osteoporosis among women in Salvador: a cross sectional study. BMC Musculoscelet Disord 2004; 5: 29

28. Patil Sapna S, Hasamnis Ameya A, Jena S, et al. Low awareness of osteoporosis among women attending an urban health centre in Mumbai, Western India. Malas J Public Health Med 2010; 10: 6-13.

29. Spencer S. Lack of knowledge of osteoporosis: a multi-centre, observational study. Scott Med J 2007; 52: 13-16.

30. Aillinger R, Emerson J. Women's knowledge of osteoporosis. Appl Nurs Res 1998; 11: 111-114. 